\title{
Ebru Sönmez,
}

\section{Idris-i Bidlisi Ottoman Kurdistan and Islamic Legitimacy,}

İstanbul: Libra Kitap, 2012, 190 pp., ISBN: 978-605-4326-56-3.

Ebru Sönmez's book, Idris-i Bidlisi Ottoman Kurdistan and Islamic Legitima$c y$, is an ambitious and broad-ranging study covering Bidlīsīs biography, his role in the administration of Ottoman Kurdistan, and his significant contributions to the religio-political debates of the sixteenth century. ${ }^{1}$ Organized into three chapters, the book centers on a political and intellectual biography of Bidlīsī, and his role in the Ottoman-Safavid conflict.

The first chapter is dedicated to situating Bidlīisi (d. 1520) within the political and cultural ambit of the sixteenth century. Sönmez provides sample biographical details, discussing Bidlisi's early life, education, and career in Iran within the formative context of the intellectual atmosphere of Aqquyunlu Tabriz. Sönmez shows how Bidlisis's education propelled him to a bureaucratic career in the Aqquyunlu palace, discusses his patronage by Ottoman Sultan Bayezid II (1481-1512) after the decline of Aqquyunlu dynasty (1501), and follows his sojourn in Mecca and his last years in Istanbul. At the same time, this chapter traces the difficulties experienced by Bidlīsī in writing his magnum opus, Hesht Behisht, and his important role in the alliance between Ottoman and Kurdish notables.

In the second chapter, Sönmez turns to a political focus, examining Bidlīsīs role in Ottoman eastern expansion policy and how he came to represent the Kurds in the eyes of the Ottoman court. In doing so, Sönmez reframes the alliance of Ottoman-Kurdish notables during this period. Her analysis overturns the narrow classical view by considering instead the role of Kurdish notables in the Ottoman-Safavid conflict at the very beginning of the sixteenth century. Based on information provided in the writings of Bidlīisi, Sönmez reconstructs the geography of Kurdistan, and deals with issues such as legitimacy debates concerning the origins of Kurdish notables, the religion of Kurds, and neighboring dynasties and their relationships with Kurds through marital partnerships.

1 Ebru Sönmez, An Acem Statesman in the Ottoman Court: İdris-i-Bidlîsî and the making of the Ottoman policy on Iran (Unpublished M.A. Thesis,Boğaziçi University, 2006). For currently published version of this thesis see, Ebru Sönmez, Idris-i Bidlisi Ottoman Kurdistan and Islamic Legitimacy, (Istanbul: Libra Kitap, 2012.) 
Within the framework of the Ottoman-Safavid rivalry, Sönmez touches upon Bidlīsīs endeavors to ally Kurdish notables with Ottomans. In particular, she depicts Bidlīsīs perspective on Kurdish notables, clarifying that Bidlīsī consciously presented the Kurdish notables to Selim I from an Ottoman vantage-that is, depicting the Kurds as religious enough to volunteer for military service against the Safavids. The political alliance of Kurdish notables with Aqquyunlu, the Safavids, and the Ottomans in order to assure Kurdish political survival is another important point dealt with in this chapter.

The third and final chapter discusses Bidlisisis contribution to religio-political debates within the Ottoman-Safavid rivalry. Primarily based on Selimşahname, the chapter reconstructs Bidlisis's attempts to portray an ideal Ottoman ruler as universal caliph-sultan.

In her work, Sönmez strives to contextualize her analysis from a new vantage point, and in doing so makes a contribution to Bidlīsī studies. At the same time, this study is restricted by an almost exclusive reliance on secondary sources. The careful incorporation of primary sources authored by Bidlīsī in both Persian and Arabic could have prevented the reproduction of errors contained in previous studies, such as Mehmet Bayrakdar's brief and skewed biography of Bidlīsi and the articles by Nazmi Sevgen on Bidlīsīs activities at the Ottoman-Safavid borderland. Utilizing these unreliable sources contradicts Sönmez's intention to approach this topic from a different point of view.

In the first chapter, covering Bidlīsis's biography, several mistakes appear as a result of the omission of Bidlisisis corpus. For instance, based on a line in Hoca Sadeddin's Tacǜt Tevarih, Sönmez claims that Bidlīsìs father Hüsameddin Bidlīsī performed the task of divan-ı inşa at the Aqquyunlu court (p. 30). Had the chronicle been carefully examined, however, it would have become clear that the münşi in question was actually Idris-i Bidlīsī, rather than his father, as Sönmez claimed. ${ }^{2}$ An analysis of the extant manuscripts and letters of Bidlisī reveals that the political identity erroneously ascribed to Hüsameddin Bidlīin contradicts his sufi identity. Further, Sönmez claims that as an individual of sufi provenance, Hüsameddin Bidlisīss presence at the Aqquyunlu court is related to Uzun Hasan's Kurdish policy. Specifically, she says that Hüsmeddin Bidlīsī was placed in that position to serve as an intermediary between Kurdish notables and Uzun Hasan, an analysis that - from the perspective of a devoted Nurbakhshī derwish outside

2 Hoca Sadeddin Efendi, Tâcüt-Tevârîh, vol. 2 (İstanbul: Tabhâne-i Âmire, 1279), 566. 
of the political ambit-does not appear to be in accordance with his sufi identity and the nature of sufi circles in which he was involved (p. 31).

Another argument that appears to be problematic is Sönmez's claim that as an opponent of Shah Ismail, Bidlīisi left Iran by rejecting his newly established ideology. The information she provides about Bidlīsīs departure from Tabriz conflicts with what Bidlīsī himself asserts. Sönmez argues that after the promulgation of the Twelve Imams Shiite in Iran, Bidlīsī refused Ismail's summon and, rejecting his rulership, left Iran. This presentation of the promulgation of the Twelve Imami Shiite as the sole reason for his departure presents Bidlīsī as a bigoted Sunni, a position contradicted by Bidlīsīs approach to patronage relationships and the wider perceptions of patronage across the contemporary Islamic world. Furthermore, Bidlīisi himself was of a Shiite-Nurbakhshī background, was under the service of Shah Ismail for a while before his departure, and wrote that it was the chaotic atmosphere of Tabriz at the start of the sixteenth century which prompted him to leave the city (sometime between 907-908/1502, rather than 1500, as Sönmez asserts). ${ }^{3}$

Sönmez also claims that Bidlīisi began to write his Selim Şâh-nâme and Kanun-i Şehinşâh after he returned from Cairo to Istanbul (p. 60). In fact, he began to compose Selimşahname when he was in the Ottoman-Safavid borderland performing his diplomatic activities and sending comprehensive Persian reports about these activities. Selimşahname was, indeed, an uncompleted book of rough drafts which Bidlīsì did not intended to rewrite after he fell out favour with Selim in Cairo in 1517. Kanun-ı Şehinş̧ah, on the other hand, is a political treatise, which was presented to Şehzade Şehinşah, Bayezid's prince, not to Süleyman the Lawgiver, as Sönmez asserts. ${ }^{4}$

Several other important points are recounted erroneously by Sönmez, the most important of which are as follows: that Bidlīsi was unable to write Turkish, that he chose to stay in Mecca in 1512 because he wanted to go to Cairo from there, that he was sent from Amasya to Kurdistan to make an alliance between the Ottomans and Kurdish notables, that he was assigned as qadi-asker of Arab

3 Vural Genç, "Şah ile Sultan Arasında Bir Acem Bürokratı: İdris-i Bidlîsî̀nin Şah İsmail’in Himayesine Girme Çabası", Osmanlı Araştırmalar//The Journal of Ottoman Studies XLVI (2015): 43-75.

4 Vural Genç, “Acem’den Rum'a”: İdris-i Bidlîsîn nin Hayatı, Tarihçiliği ve Heşt Behişt' in II. Bayezid Kısmı (1481-1512)” (Unpublished Ph.D Diss., Istanbul University, 2014), 1-3, 205-207. 
and Ajam after the conquest of Diyarbekir, and that he returned to Istanbul passing through Diyarbekir after the campaign of Egypt. These assertions should be corrected as follows: first, based on his Turkish correspondence with courtiers of Bayezid II, Bidlīsī was evidently able to write Turkish. Second, Bidlīsī never intended to stay in Cairo, on the contrary he chose to stay in Mecca for some time to establish his relationship with Shah Ismail. Third, he was sent from Marand for diplomatic activities rather than Amasya (p. 90). Fourth, there is no evidence to support the assertion that Bidlīsi was appointed as qadi-asker of Arab and Ajam except Âşıı Çelebi’s account (p. 59); neither Bidlīsī nor his son Ebulfazl mention this administrative assignment. Finally, Bidlisī returned to Istanbul in the summer of 1517 via seaway after the campaign of Egypt. A comprehensive utilization of Bidlisisiss corpus would have eliminated these errors, furthering the utility of Sönmez's otherwise excellent construction of Bidlīsīs biography.

For the second chapter of the book, Sönmez relies principally on Bidlisis’s Selimşahname as well as his diplomatic reports, which were written in Persian and sent to Yavuz Sultan Selim, in order to develop her arguments regarding Bidlīisiss ties with Kurdish notables and his prestige amongst them. Sönmez exaggeratively identifies Bidlīsīs self-representation as someone with strong ties to Kurdish notables; however she fails to question this claim. While the Sheref Khan family, rulers of Bidlis, was the most prestigious dynasty amongst the Kurdish notables, it would be incorrect to assume that Bidlisīi had particularly close relations with them. Despite his connection to a Kurdish family from Bidliss, as a bureaucrat of Iranian provenance he spent two-thirds of his life in Iran. Sönmez asserts that when he was sent to Kurdistan to advocate on behalf of Selim Bidlīisi had no strategy of his own. Like other Kurds operating between both the Ottoman and Safavid realms, however, Bidlīisi used the Ottoman-Safavid conflict to his personal advantage. It is not safe to assume, as Sönmez does, that Bidlīsī did not have a clear strategy when he was sent to Kurdistan by Selim in order to further the sultan's propaganda. On the contrary, in order to establish a strategic partnership, Sönmez focused his propaganda on those Kurdish notables who suffered from Shah Ismail's violence. Another point worth mentioning is the portrayal in this study of Kurdish identity in the sixteenth-century Ottoman world. Under the influence of both Idris-i Bidlīsī and Sharaf Khan Bidlīsīs worldview, Sönmez represents the Kurds almost as a Sunni community. Even though Idris-i Bidlīsī and Sharaf Khan Bidlisīi prefers to represent the Kurds as bigoted Sunni community, 
in their accounts both admit the considerable existence of Yezidi and Qizilbash Kurds. ${ }^{5}$

Missing in Sönmez's accounts are the nature of Bidlisisiss religious propaganda as a "mobile preacher" among the Kurds, which made a mark on his all activities, as well as the response to this activities by Shah Ismail. Even though she analyzes the nature of relationships among Kurdish notables, their mutual hostilities, and Shah Ismail's policy towards them, Sönmez does not provide any information about the propaganda methods employed effectively on both sides. She regards Bidlīsīs extensive intelligence activities as preparations made by Selim before his impending conquests, whereas during this time Bidlīsī in fact continued his intelligence activities in a vast area spanning from Khurasan to Khuzistan, and from Revan to Shiraz and Baghdad, to gather intelligence on the Safavids.

The sources utilized by the author also pose some problems in the second chapter. Rather than employing the reports Bidlīsī penned and sent to Selim, Sönmez prefers to cite Sevgen's brief translations, thus reproducing his errors. ${ }^{6}$ For instance, Sönmez has alloyed the contents of the TSMA. E. 8333/1 with another report numbered TSMA. E. 8333/2. Specifically, she presents TSMA. E. 8333/1 as TSMA. E. 8333/2 (pp. 91-92, 99-101). A similar mistake occurs with TSMA. E. 8333/2. Finally, Sönmez misread some geographic and demographic names, such as "Kulh", "Ağli" and "Masansi" (?) (p. 100). The correct reading is Kalhur, Aqili and Mush'ash'a, respectively.

Sönmez's use of Risāletüll-Hilâfe ve Ādābu's-Selâtin vèl-Vüzerâ and Kanun-ı Şehinşâh in the last chapter of her book was also problematic. Risäletül-Hilâfe ve Ädābu's-Selâtin ve'l-Vüzerâ is cited repeatedly, despite the fact that it has been misattributed to Bidlīsī. See the review cited below for discussion of this matter. ${ }^{7}$

The use of Kanun-ı Şehinşâh is relatedly problematic. In order to substantiate her claims about the image of the Ottoman caliph-sultan during the reigns

5 Sharaf Khan Bidlīsī, Sharafnāma: Tarikh-e Mufassal-e Kurdistan, ed. V. Veliaminof Zernof, vol. 1, (Tehran, 1377), ff.; for Bidlīsīs reports see, Vural Genç, “İdris-i Bidlîsînnin II. Bayezid ve I. Selim'e Mektupları”, Osmanl Araştırmaları/The Journal of Ottoman Studies XLVII (2016): 147-208.

6 Sevgen's translation is replete with errors. For these in detail assesments see. Genç, "İdris-i Bidlîsî̀nin II. Bayezid ve I. Selim’e Mektupları.”

7 Vural Genç, "A Criticial Review on an Epistle Attributed to Idrīs-i Bidlīsī: Risālat al-Khilāfa va Ādāb al-Salātīn va al-Wuzarā," Journal of Ottoman Studies 49 (2017). 
of Selim and Süleyman, Sönmez argues that Kanun-ı Şehinşâh was completed sometime between the reigns of these two rulers. Moreover, she claims that Bidlīsī theorized and formulated these two Ottoman sultans (Selim and Süleyman) as ideal and just rulers in Kanun-ı Şehinşâh. It has been demonstrated recently, however, that the aforementioned manuscript was presented to Bayezid's eldest prince, Şehinşah, rather than to Selim or Süleyman, as claimed by both Sönmez and Hüseyin Yılmaz, her main source for this argument. ${ }^{8}$ Based on a manuscript written sometime between 1508-09, Sönmez erroneously attributes the vision of rulership in the reign of Selim and Süleyman to an earlier period. She also claims that Bidlisin completed this work after the Iran and Egyptian campaigns, thus idealizing the Ottoman imperial image and its superiority in the Muslim world as a result of his experience during the tumultuous era in which the Ottoman-Mamluk and Ottoman-Safavid conflicts occured (pp. 8, 105, 114-115) Bidlīsī, however, had formulated these claims of universal superiority for Bayezid II before the Iran and Egyptian campaigns. This chronological confusion results in another unsubstantiated conclusion: namely, that Bidlīsī must have had the last caliph, al-Mutawakkil, in mind while writing about the shadow of God on earth and the uniqueness of God's vice-regent ( $\mathrm{p}$. 161). Accordingly, some of the assertions and questions raised by Sönmez based on Risäletül-Hilâfe ve Ädäbu's-Selâtin ve’l-Vüzerâ and Kanun-ı Şehinşah, are invalid. For example, her discussions of the way in which Bidlīsī represented Safavid's rival Ottomans and depicted Selim as a just and ideal ruler, of how political development occurring in the reign of Selim changed the vision of rulership in the Islamic world, and correspondingly concerning how Ottoman sultans were represented as universal rulers across the Islamic world. Her conclusions to these issues are based on an anachronistic reading of the manuscript completed during the reign of Bayezid II.

Also in this final chapter, while mentioning the fact that Bidlisī refuted Shah Ismail's universal claims and his divinity, it would be appropriate if Sönmez could correlate Bidlisišs world of thought with his patronage relationships. It is known that Bidlīisi formulated the caliph-sultan image for Ottoman sultans, particularly for Selim. However, that he formulated the same image for Shah Ismail when he was in Mecca shows that Bidlīisi could construct such images for anyone who

8 Genç, “Acem'den Rum'a," 205-207. 
would become his new patron, just as his comtemporaries. ${ }^{9}$ Hence this is not a unique formulation by Bidlīī for Ottoman sultans.

By employing a new approach Sönmez has certainly made some important contributions to the field. Her work, however, could be strengthened through a more comprehensive reliance on and analysis of Bidlisisis corpus, and a more critical reading of existing secondary works in the field.

Vural Genç

Istanbul University

\section{Ahmed Hamdi Tanpınar, Beş Şebir,}

Açıklama ve notlarla yayına hazırlayan: Beşir Ayvazoğlu, İstanbul: Dergah Yayınları, 2016, 359 s., ISBN 978-975-7462-33-0

Bazı düşünürler, sanatkârlar ve yazarlar verdikleri eserlerden ötürü zamanlarından çok yarına ait olurlar ve gelecek dönemlerde yaşarlar. Hayattayken hak ettiği farkındalığa nâil olamasa veya bunu bir şekilde yaratamasa bile bir gün okuyucusunu ve gözleyicisini bulabileceğine duyduğu güven içinde kendini amansızca eserlerine adarlar, adeta çilehaneye dönen köşelerinde münzevi bir hayat sürerler. Bu fikri, düşünceyi kağıda dökmenin bedelidir!

"Bir gün elbette bana döneceklerdir" diyen Ahmed Hamdi Tanpınar şüphesiz bu grubun içinde yer alır. Tanpınar’ın, Beşir Ayvazoğlu’nun özenli emeği ve dikkatli notlandırmalarıyla ve Dergah Yayınlarının da başlı başına teşekkürü hak edecek itinalı baskısıyla tekrar okuyucuyla buluşan 359 sayfalık Beş Şehir kitabı, bu dönüşü gerçekleştiren parlak bir örnek olmuştur. Ele alındığında ve incelediğinde muhatabına karşısında sadece saygıyla durulması gerektiği hissini veren bir çalışma, eleştirilecek bir şeyler arayanları hayal kırıklığına uğratacak bir yayın ... Tanpınar'ın metnini çeşitli arşivlerden derlediği resimlerle zarif bir şekilde dona$\tan$ Ayvazoğlu, hem ruhu doyuran hem de okuyucuyu derin düşüncelere sevk eden başka boyutlarla karşı karşıya bırakmaktadır.

9 Fazl Allah Khunji Isfahānī (d. 1521), an Aqquyunlu courtier in the reign of Sultan Yaqub (d. 1490) who sought the patronage of Muhammad Shibānī Khān (d. 1510) Uzbek ruler after the decline of Aqquyunlu dynasty, would be an exemplary for this. He formulated the same images for both Aqquyunlu and Uzbek rulers. 
Beş Şehir'in, özellikle İstanbul bölümünün bütün okumalarımın içinde ayrı bir yeri vardır. Öyle ki bazen, her firsat bulduğumda ve aklıma geldiğinde İstanbul'a yüksek eğitim için gelenlerin veya bu şehirde eğitim alanların, İstanbul'da üniversite eğitimi görmeleri sebebiyle bu kentin onlardan bir alacağı olduğunu ve borçlarını ancak bu kitabı ve özellikle de bunun İstanbul bölümünü okumakla bir az olsun ödeyebileceklerini söyler dururum. İlk baskısı 217 sayfa halinde 1946'da yapılan bu eserin yeni baskısını her halde artık bu ifadenin kapsamı içine alabilirim. İstanbul gibi şehirler tarihinin, kültürle yoğrulmuş doğasının ve Hâlık'ın bahşettiği konumunun mecrasını takip etmelidirler. Ancak şehrin Fatihi'nin kâbus gibi algılayacağına emin olduğumuz telâfisi mümkün olmayan bazı akıbetlerinin bu okumayı daha da hüzünlü bir havaya sokacağından şüphe duymamaktayız.

Başta vakanüvis tarihleri ve seyahatnameler olmak üzere Türk kültürünün temel kaynaklarını dikkatle okuyan Tanpınar'ın Beş Şehir'de anlattıklarını Beşir Ayvazoğlu, özenle tahkik ve kaynaklarını kontrol etmiştir. Sadece tarihi eserleri değil, söz gelimi Tanpınar'ın, Bursa bölümünde erguvanlardan bahsederken Manavkadı Camii'nin harabe duvarları arasından firlayan erguvan ağacı kendisine gösterildiği günden itibaren her bahar orayı nasıl ziyarete gittiğini ifade eden notları, hassas şair inceliğinin bir tezahürü olsa gerektir.

Ayvazoğlu, Tanpınar'ın notlarında yer alan bazı bilgi hatalarına da işaret eder. Ancak bunların belki hatadan ziyade âdeta birer hafıza yanılmaları olduğu ve eserin edebî değerine en ufak bir halel getirmediği özellikle vurgulanır. Bu bağlamda Tanpınar'ın eserlerini verdiği dönemde hem kaynaklara ulaşmanın ve hem de bilgileri tahkik etme imkânının pek kolay olmadığına dikkat çekilir. Beş Şehir'de okuyucuyu büyüleyen temel husus, seyahatname veya tarihi kayıtlarında geçen bilgiler değildir. Her hangi biri kullandığında moloz yığınına dönüşebilecek olan bu tür bilgileri Tanpınar'ın üslûbu adeta bir masala çevirir. Yine de o kendi masalını yaratmaktan ziyade, şehrin yaşanan tarih ve kültür ile harmanlanmış özgün dokusunu kendine mahsus bir duyuş ve ifadeyle gözler önüne serer. Tanpınar bu temaşayı okurlarına sunar, Ayvazoğlu ise bunun muhteşem bir şekilde servis edilmesini üslenir. Bu durumda birine rahmet diğerine teşekkür etmek okuyucu için zevkli bir vazife olmalıdır.

\section{Seyfi Kenan}

